Syntax Idea: p-ISSN: 2684-6853 e-ISSN: 2684-883X

Vol. 3, No. 9, September 2021

\title{
IDENTIFIKASI SPASIAL KUALITAS LINGKUNGAN PERMUKIMAN KUMUH DI KELURAHAN SEMANGGI KOTA SURAKARTA
}

\section{Andhika Bangun Taji}

Magister Teknik Perencanaan Wilayah dan Kota UGM Yogyakarta, Indonesia

Email: andhika.btj@gmail.com

\begin{abstract}
Abstrak
Penelitian ini mengkaji kualitas lingkungan permukiman kumuh di daerah pinggiran kota khususnya di Kelurahan Semanggi Kota Surakarta. Tujuan penelitian ini adalah (1) Menjelaskan kualitas lingkungan permukiman kumuh di Kelurahan Semanggi setelah adanya program KOTAKU, (2) Mengidentifikasi faktor dan variabel yang berpengaruh terhadap kualitas permukiman Kumuh Kelurahan Semanggi. Metode penelitian yang digunakan dalam penelitian ini metode penelitian deduktif kuantitatif. Teknik sampling yang digunakan adalah teknik proporsional random sampling. Responden penelitian ini adalah kepala keluarga yang berasal dari data verifikasi keluarga miskin Kota Surakarta tahun 2019. Teknik analisis data dengan menggunakan metode interpretasi penginderaan jauh, skoring dan pembobotan, uji korelasi Spearman, uji regresi ganda dan analisis deskriptif kualitatif dengan menggunakan tabel silang. Hasil penelitian ini adalah (1) Kelurahan Semangi pada tahun 2021 setelah adanya program KOTAKU telah berhasil menurunkan luasan kekumuhan dari 76,03 ha menjadi 18,36 ha. Pengurangan tersebut antara lain sebesar 38,05 ha (50,04\%) mempunyai kualitas lingkungan permukiman baik, dan sebesar 19,62 ha (25,72\%) mempunyai kualitas lingkungan permukiman sedang; (2) Dari hasil uji statistik regresi linier berganda didapatkan hasil bahwa faktor-faktor yang berpengaruh terhadap kualitas lingkungan permukiman adalah kepadatan bangunan, keteraturan bangunan dan pengelolaan persampahan dan yang kurang berpengaruh adalah tingkat penghasilan kepala keluarga dan tingkat pengeluaran kepala keluarga.
\end{abstract}

Kata Kunci: kualitas lingkungan permukiman kumuh; penginderaan jauh; program KOTAKU

\section{Abstract}

This study examined the quality of the slums in suburban areas, especially in Semanggi Village of Surakarta City. The purpose of this study is (1) Explaining the quality of slum environment in Semanggi Village after the KOTAKU program, (2) Identifying factors and variables that affect the quality of Semanggi Village Slums. The research methods used in this research are quantitative deductive research methods. The sampling technique used is a proportional random sampling technique. Respondents to this study are the heads of families derived from the verification data of poor families of Surakarta City in 2019. Data analysis techniques using remote sensing interpretation methods, scoring and weighting, Spearman correlation tests, double regression tests and qualitative descriptive analysis using cross tables. The

$\begin{array}{ll}\text { How to cite: } & \text { Taji, A. B., (2021) Identifikasi Spasial Kualitas Lingkungan Permukiman Kumuh Di Kelurahan } \\ & \text { Semanggi Kota Surakarta. Syntax Idea, 3(9), https://doi.org/10.36418/syntax-idea.v3i9.1459 } \\ \text { E-ISSN: } & \text { 2684-883X } \\ \text { Published by: } & \text { Ridwan Institute }\end{array}$


Identifikasi Spasial Kualitas Lingkungan Permukiman Kumuh Di Kelurahan Semanggi

Kota Surakarta

results of this study are (1) Semangi Village in 2021 after the KOTAKU program has succeeded in reducing the area of suffoy from 76.03 ha to 18.36 ha. The reduction included 38.05 ha (50.04\%) has good residential environmental quality, and 19.62 ha $(25.72 \%)$ has moderate residential environmental quality; (2) From the results of the double linear regression statistical test, the results found that the factors that affect the quality of the residential environment are the density of buildings, the regularity of buildings and the management of sposs and the less influential is the income level of the head of the family and the level of expenditure of the head of the family.

Keywords: quality of slum environments; remote sensing; KOTAKU program

Received: 2021-08-22; Accepted: 2021-09-05; Published: 2021-09-20

\section{Pendahuluan}

Perumahan sering dikaitkan dengan istilah perumahan rakyat. Perumahan rakyat adalah sekelompok rumah atau tempat kediaman yang layak huni dan dilengkapi dengan prasarana lingkungan, utilitas umum, maupun fasilitas sosial yang dibangun bagi kepentingan rakyat, sehingga dapat diartikan sebagian besar penghuni perumahan rakyat adalah masyarakat berpenghasilan rendah (Mutaáli, 2016). Permukiman kumuh salah satunya berasal dari banyaknya lapangan pekerjaan yang tersedia di kota sehingga menarik minat masyarakat untuk mencari nafkah di kota.

Kurangnya ketersediaan lahan dan peningkatan kebutuhan perumahan mengakibatkan banyak masyarakat berpenghasilan rendah memilih kawasan peri urban sebagai tempat tinggal (Dewi \& Idajati, 2020). Perkembangan kawasan permukiman kumuh (slum area) yang tidak terencana (spontan) dan tidak teratur terjadi hampir di sebagian besar kota-kota di Indonesia (Banawi, 2017). Kelurahan Semanggi yang terdapat di kawasan pinggiran Kota Surakarta juga mengalami gejala seperti ini, dimana permukiman mempunyai kecenderungan tumbuh dengan cara mengisi ruang - ruang pada lahan yang kosong dengan membangun rumah untuk dijadikan tempat tinggal (Sabila, 2019), sehingga terjadi pertumbuhan pembangunan yang pesat di pinggiran kota.

Pertumbuhan yang ada di sektor pembangunan lingkungan perkotaan adalah akibat gelombang urbanisasi yang di pacu oleh pembangunan infrastruktur sarana dan prasarana kota yang meerupakan daya tarik sekaligus gaya dorong bagi para warga yang ingin memperoleh peluang kehidupan lebih baik. pembangunan prasarana dan sarana tidak hanya diperuntukan bagi segelintir pemanfaat namun harus bisa juga dirasakan oleh masyarakat luas, khususnya warga miskin (Nurhasanah, 2019).

Permukiman kumuh merupakan salah satu masalah dan tidak diharapkan keberadaannya oleh masyarakat, maka dari itu dalam RPJMN 2015-2019 Pemerintah Indonesia telah menetapkan target pengentasan permukiman dengan program "Gerakan 100-0100", yakni pencapaian akses air minum $100 \%$, mengurangi keberadaan permukiman kumuh hingga $0 \%$, dan menyediakan sanitasi layak $100 \%$ untuk masyarakat Indonesia di tahun 2019 (Muvidayanti, 2018). 
Di dalam dokumen Rencana Pencegahan dan Peningkatan Kualitas Permukiman Kumuh Perkotaan (RP2KPKP) Kota Surakarta Tahun 2017, disebutkan bahwa Kelurahan Semanggi sebagai bagian administrasi dari Kota Surakarta merupakan lokasi kumuh dalam delineasi SK Walikota Surakarta No. 413.21/38.3/1/2016 yang mempunyai lokasi strategis karena terletak di perbatasan dengan Kabupaten Sukoharjo dan Kelurahan Semanggi menjadi salah satu kelurahan prioritas pelaksanaan program KOTAKU, dan terdapat rencana aksi penanganan kawasan kumuh perkotaan yang bertujuan mencapai 0\% kawasan kumuh pada tahun 2021.

Salah satu penanganan kawasan kumuh adalah melalui kegiatan peningkatan maupun pembangunan prasarana-sarana baru, baik dari segi perumahan maupun kawasan permukiman yang terjangkau dan layak huni (Hariyanto, 2010). Program KOTAKU (Kota Tanpa Kumuh) adalah program yang dilaksanakan oleh Kementrian Pekerjaan Umum dan Perumahan Rakyat dengan tujuan untuk peningkatan kualitas permukiman kumuh, pencegahan tumbuh kembangnya permukiman kumuh baru dan penghidupan yang berkelanjutan (Umum, 2016). Dalam penelitian ini, variabel fisik yang digunakan adalah a). bangunan Gedung, b). jalan lingkungan, c). drainase lingkungan, d). pengelolaan persampahan, e). pengelolaan air limbah, f). sistem penyediaan air minum dan g). proteksi kebakaran.

Penelitian mengenai evaluasi program KOTAKU selama ini masih dilakukan dengan melakukan evaluasi hasil dari program KOTAKU (Maulana \& Nurhaeni, 2019). Evaluasi program KOTAKU juga dilakukan dengan melihat dari evaluasi persepsi masyarakat terhadap peningkatan kualitas lingkungan permukiman setelah adanya program KOTAKU (Liandri, 2019). Evaluasi penting dilakukan untuk mengetahui efektivitas hasil implementasi program, faktor yang mempengaruhi keberhasilan dan prospek keberlanjutan pelaksanaan program (Sinaga, 2018). Hasil dari kedua penelitian ini menunjukkan bahwa terdapat peningkatan kualitas lingkungan permukimn setelah adanya program KOTAKU yang ditunjukkan dengan adanya perbaikan - perbaikan sarana dan prasarana fisik perkotaan.

Faktor fisik yang berpengaruh terhadap kualitas lingkungan permukiman antara lain keteraturan bangunan dan kondisi bangunan rumah (Ekartaji, Yunus, \& Rahardjo, 2016). Faktor tersebut mengakibatkan bervariasinya kualitas lingkungan permukiman di Desa Ngestiharjo Yogyakarta. Selain faktor fisik, kualitas lingkungan permukiman kumuh juga ditentukan oleh faktor sosial budaya dan ekonomi (Krisandriyana, 2017). Sehingga faktor yang mempengaruhi kualitas lingkungan permukiman kumuh dapat dikaji dari ketiga faktor yaitu faktor fisik, faktor sosial dan faktor ekonomi masyarakat yang tinggall di kawasan tersebut.

Data penginderaan jauh dapat diekstrak untuk mengetahui dan memperoleh informasi di permukaan bumi. Informasi-informasi tersebut disatukan dengan bantuan aplikasi SIG yang akan mengerucut ke satu tema yang diinginkan (Ghozali \& Sudaryatno, 2016). Pemanfaatan tekhnologi penginderaan jauh dalam penilaian karakteristik fisik permukiman kumuh yang terintegrasi dengan data sosial ekonomi merupakan hal yang baru dalam penelitian mengenai evaluasi permukiman kumuh, 
selain itu teknologi penginderaan jauh yang dapat menganalisis data tanpa kontak langsung dengan wilayah penelitian sangat berguna terutama dalam masa pandemi COVID - 19 seperti sekarang ini.

Hasil penelitian ini juga bertentangan dengan penelitian terdahulu yang menyatakan bahwa terdapat hubungan yang berbanding lurus antara karakteristik faktor ekonomi dengan kualitas permukiman, dimana semakin baik karakteristik faktor ekonomi maka kualitas permukiman juga akan semakin baik (Daniella \& Widyastuti, 2019).

Berdasarkan pertimbangan tersebut, perlu dikaji dan diidentifikasi secara spasial apakah ada hubungan antara meningkatnya kualitas lingkungan permukiman dengan faktor-faktor pembentuk permukiman kumuh yang terdiri dari 3 macam faktor yaitu faktor fisik, faktor sosial dan faktor ekonomi serta faktor dan variabel mana yang paling berpengaruh dan apakah luas permukiman kumuh sebelum adanya program KOTAKU di Kelurahan Semanggi menjadi berkurang setelah adanya program KOTAKU.

\section{Metode Penelitian}

Penelitian mengenai Dampak Program KOTAKU terhadap kondisi lingkungan sekitar di Kota Surakarta ini dilakukan dengan menggunakan metode penelitian deduktif kuantitatif. Metode penelitian deduktif adalah metode penelitian yang dilakukan dengan pendekatan secara teoritik untuk mendapatkan konformasi berdasarkan hipotesis dan observasi yang telah dilakukan sebelumnya (Sugiyono, 2009). Penelitian dilakukan dengan cara integrasi antara penginderaan jauh dengan data sekunder yaitu data verifikasi keluarga miskin Kota Surakarta.

Lokasi yang dipilih adalah Kelurahan Semanggi di Kota Surakarta. Kelurahan Semanggi dipilih karena merupakan lokasi prioritas program KOTAKU dan terletak di pinggiran Kota Surakarta. Selain itu, Kelurahan Semanggi mempunyai karakteristik kumuh ringan dan rawan bencana banjir kota yang mengakibatkan rusaknya sarana dan prasarana permukiman.

Jenis data yang digunakan dalam penelitian ini adalah data primer yang diperoleh dari hasil interpretasi citra satelit SPOT 5 Kota Surakarta tahun 2018 dan data sekunder yang berasal dari data verifikasi keluarga miskin Kota Surakarta tahun 2018. Analisis data yang digunakan untuk menentukan tingkat kualitas lingkungan permukiman kumuh adalah dengan skoring atau pemberian bobot pada masing-masing parameter. Sedangkan untuk mengkaji hubungan kualitas lingkungan permukiman kumuh dengan faktor fisik dan faktor sosial ekonomi yang mempengaruhinya menggunakan korelasi spearman rank (Hidayah, Budiati, \& Permadi, 2018).

\section{Hasil dan Pembahasan}

Kelurahan Semanggi sebelum adanya program KOTAKU memiliki karakteristik kumuh perkotaan yang mayoritas terletak di bantaran sungai Bengawan Solo dan sungai pepe dan bantaran rel kereta api serta rawan bencana banjir kota dan mempunyai luas permukiman kumuh sebesar 76,03 ha. Berdasarkan perhitungan luas permukiman 
kumuh di Kelurahan Semanggi, didapatkan hasil bahwa luas blok permukiman dengan kualitas lingkungan permukiman buruk di Kelurahan Semanggi pada tahun 2020 adalah seluas 18,36 ha. Artinya, luas blok permukiman kumuh di kelurahan Semanggi telah berkurang sebanyak 57,67 ha.

Berdasarkan perhitungan harkat kualitas lingkungan permukiman yang didapatkan dari interpretasi citra satelit SPOT 5 dan pengamatan lapangan, maka didapatkan nilai skor kualitas lingkungan permukiman berdasarkan analisis spasial didapatkan skor yang memiliki nilai antara 21 - 63. Tiga kategori tersebut yaitu blok permukiman dengan kualitas lingkungan permukiman baik memiliki range nilai 43 - 63, blok permukiman dengan kualitas lingkungan permukiman sedang memiliki range nilai $34-42$ dan kemudian blok permukiman dengan kualitas lingkungan buruk dengan range nilai dari $21-33$.

Tabel 1

Nilai skor per kelas kualitas lingkungan permukiman menurut analisis citra satelit SPOT 5 di Kelurahan Semanggi

\begin{tabular}{|c|c|c|}
\hline No & Klasifikasi & Skor \\
\hline 1 & Baik & $43-63$ \\
\hline 2 & Sedang & $34-42$ \\
\hline 3 & Buruk & $21-33$ \\
\hline
\end{tabular}

Sumber : Hasil interpretasi citra satelit SPOT 5 dan survey lapangan tahun 2020.

Berdasarkan hasil pemetaan didapatkan hasil bahwa daerah yang memiliki kualitas lingkungan permukiman baik, rata - rata terletak di wilayah yang mempunyai posisi strategis seperti dilalui jalan kolektor dan dekat dengan pusat ekonomi seperti pasar nitiharjo. Kebijakan pengurangan permukiman kumuh difokuskan di daerahdaerah di pinggiran sungai Bengawan Solo dan rel kereta api. Hal ini disebabkan kebijakan pengurangan permukiman kumuh di Kelurahan Semanggi menggunakan strategi utama yaitu meningkatkan pemberdayaan masyarakat dalam pemenuhan rumah sehat dan lingkungan yang layak huni. Dengan peningkatan ekonomi, maka diharapkan masyarakat dapat mengakses perbaikan dan pemeliharaan rumah menjadi layak, perbaikan dan pemeliharaan infrastruktur, serta mampu mendapatkan rumah yang berdiri di atas tanah legal sesuai dengan peruntukannya sehingga, permasalahan lain baik yang menyebabkan kekumuhan atau akibat kekumuhan dapat diminimalkan.

Apabila dilihat dari sebarannya, blok permukiman dengan kualitas lingkungan permukiman baik tersebar merata di setiap RW maupun RT yang ada di Kelurahan Semanggi. Karakteristik permukiman di blok permukiman ini pada umumnya mempunyai kepadatan dan keteraturan bangunan yang relatif rendah dan lebih teratur serta memiliki sarana - prasarana permukiman yang lebih lengkap dan memadai seperti pembuangan sampah, drainase yang baik serta kondisi jalan yang sudah diperkeras dengan aspal.

Blok permukiman dengan kualitas sedang juga tersebar merata di setiap kelurahan yang ada di Kelurahan Semanggi. Karakteristik dari kualitas lingkungan permukiman tersebut adalah mempunyai kepadatan dan keteraturan bangunan sedang, memiliki 
sarana dan prasarana permukiman yang cukup seperti drainase yang baik, kualitas jalan yang diperkeras dengan semen / konblok namun tidak sebagus blok permukiman dengan kualitas lingkungan permukiman baik. Secara umum, lokasi blok permukiman dengan kualitas lingkungan permukiman sedang ini berada di tepi rel kereta api, dan Kelurahan Semanggi sisi utara.

Blok permukiman dengan kualitas lingkungan permukiman yang buruk berumlah 108 blok permukiman (56\%). Dilihat dari prosentasenya, hampir separuh dari Kelurahan Semanggi pada tahun 2020 ini memiliki kualitas lingkungan permukiman yang buruk. Karakteristik dari blok permukiman ini adalah mempunyai kepadatan bangunan yang tinggi, keteraturan bangunan yang tidak teratur serta memiliki sarana dan prasarana permukiman yang minim seperti jaringan drainase yang buruk, fasilitas pembuangan sampah yang minim serta akses jalan yang sangat sempit dan belum diperkeras dengan aspal. Secara administratif. Lokasi blok permukiman dengan kualitas buruk ini berada di Kelurahan Sangkrah di tepi rel kereta api dan bantaran sungai Bengawan Solo.

Dari analisis spasial kualitas lingkungan permukiman apabila dilakukan pengamatan lebih lanjut, didapatkan sebuah fenomena yaitu daerah yang memiliki kualitas lingkungan permukiman baik, rata - rata terletak di wilayah yang mempunyai posisi strategis seperti dilalui jalan kolektor dan dekat dengan pusat ekonomi seperti pasar nitiharjo. Kebijakan pengurangan permukiman kumuh difokuskan di daerah daerah di pinggiran sungai Bengawan Solo dan rel kereta api. Hal ini disebabkan kebijakan pengurangan permukiman kumuh di Kelurahan Semanggi menggunakan strategi utama yaitu meningkatkan pemberdayaan masyarakat dalam pemenuhan rumah sehat dan lingkungan yang layak huni. Dengan peningkatan ekonomi, maka diharapkan masyarakat dapat mengakses perbaikan dan pemeliharaan rumah menjadi layak, perbaikan dan pemeliharaan infrastruktur, serta mampu mendapatkan rumah yang berdiri di atas tanah legal sesuai dengan peruntukannya sehingga, permasalahan lain baik yang menyebabkan kekumuhan atau akibat kekumuhan dapat diminimalkan. Strategi kedua adalah mencegah timbulnya banjir kota dan genangan. Wilayah yang berada di tepi sungai Bengawan Solo menjadi daerah yang rawan banjir dikarenakan drainase yang buruk. Timbulnya banjir kota ini menyebabkan sarana dan prasarana permukiman menjadi lebih cepat rusak dan memicu tumbuhnya kawasan permukiman kumuh.

Strategi yang ketiga adalah meningkatkan jumlah rumah layak huni, meningkatkan akses terhadap infrastruktur, serta meningkatkan upaya penyediaan rumah layak huni yang legal. Dengan adanya keterbatasan lahan, pola bermukim yang tidak teratur dan berkepadatan tinggi, serta kemampuan masyarakat yang rendah, maka salah satu upaya penanganan adalah pembangunan rusunawa yang berkapasitas 192 unit tipe 24 bagi masyarakat berpenghasilan rendah di Kelurahan Semanggi.

Selain strategi yang bersifat fisik, strategi non fisik juga diterapkan di Kelurahan Semanggi yaitu yang berkaitan dengan pola perilaku masyarakat. Kesadaran masyarakat untuk menerapkan pola hidup bersih dan sehat di Kelurahan Semanggi masih rendah, 
hal itu terlihat dari rendahnya kualitas lingkungan permukiman di daerah bantaran sungai Bengawan Solo dan tepi rel kereta api. Penduduk di Kelurahan Semanggi masih membuang sampah dengan cara dibuang ke sungai atau dibakar. Pemusnahan sampah dengan cara ini rentan menimbulkan pencemaran dan kerusakan lingkungan yang berimbas pada buruknya kualitas lingkungan permukiman. Di sisi lain, pemahaman dan pengertian penduduk di Kelurahan Semanggi masih kurang sehingga diperlukan edukasi, pengendalian dan pengawasan terhadap pembangunan permukiman dan peningkatan kesadaran masyarakat dalam perilaku hidup bersih dan sehat harus lebih ditingkatkan. Hal tersebut sejalan dengan pendekatan yang digunakan dalam penyelesaian permukiman kumuh di Indonesia yaitu mengimplementasikan pendekatan yang didasarkan pada prinsip pembangunan berkelanjutan, dimana salah satu komponennya adalah terwujudnya lingkungan permukiman yang sehat (Ervianto \& Felasari, 2019).

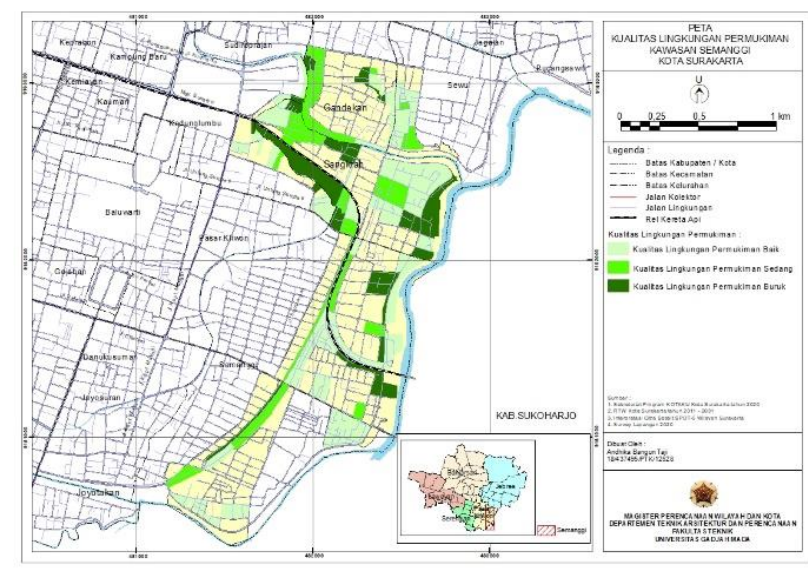

Gambar 1

Peta Kualitas Lingkungan Permukiman Kumuh Kota Semanggi

Faktor dan variabel fisik dan sosial ekonomi yang diperkirakan mempengaruhi kualitas lingkungan permukiman di kelurahan semanggi antara lain tingkat kepadatan bangunan, tingkat keteraturan bangunan, tingkat pengelolaan persampahan, tingkat pendapatan kepala keluarga dan tingkat pengeluaran kepala keluarga. Kepadatan bangunan dapat mempengaruhi kualitas lingkungan permukiman, semakin padat bangunan yang ada, maka kualitas lingkungan permukiman semakin menurun dan apabila kepadatan bangunan semakin tidak padat maka kualitas lingkungan permukiman baik. Keteraturan bangunan mempengaruhi kualitas lingkungan permukiman, hal ini dikarenakan apabila kondisi blok permukiman tidak teratur maka dapat tercipta kondisi blok permukiman yang kumuh dan acak-acakan. Tingkat layanan pengelolaan persampahan mencerminkan bagaimana tingkat pengelolaan sampah baik sampah rumah tangga maupun sampah non rumah tangga. Tingkat pendapatan kepala keluarga juga dapat mempengaruhi kualitas lingkungan permukiman, hal ini dikarenakan semakin tinggi pendapatan kepala keluarga, maka pendapatan tersebut dapat disisihkan untuk menjaga kualitas lingkungan permukiman dan tingkat pengeluaran kepala 
keluarga dapat mempengaruhi kualitas lingkungan permukiman dikarenakan apabila pengeluaran kepala keluarga melebihi pendapatan maka kepala keluarga tersebut tidak dapat menyisihkan sebagian pendapatan untuk menjaga kualitas lingkungan permukiman di sekitarnya.

\section{Tabel 2}

Statistik Uji dan Kesimpulan

\begin{tabular}{|c|c|c|c|}
\hline Variabel & P-value & $\mathbf{t}$ & Kesimpulan \\
\hline $\begin{array}{l}\text { Tingkat } \\
\text { Pendapatan Kepala } \\
\text { Keluarga }\end{array}$ & 0.271 & 1.104 & $\begin{array}{l}\text { Karena P-value lebih besar dari } \alpha \text { atau } \\
|\mathrm{t}| \text { kurang dari } \mathrm{t}(0.025 ; 192) \text { maka } \mathrm{H}_{0} \text { tidak } \\
\text { ditolak sehingga dapat disimpulkan } \beta_{2} \\
=0 \text { (koefisien tidak layak masuk } \\
\text { model regresi) atau dengan kata lain } \\
\text { variabel independen tersebut kurang } \\
\text { berpengaruh signifikan terhadap } \\
\text { variabel dependen. }\end{array}$ \\
\hline $\begin{array}{l}\text { Tingkat } \\
\text { Pengeluaran } \\
\text { Kepala Keluarga }\end{array}$ & 0.271 & 1.104 & $\begin{array}{l}\text { Karena P-value lebih besar dari } \alpha \text { atau } \\
|\mathrm{t}| \text { kurang dari } \mathrm{t}(0.025 ; 192) \text { maka } \mathrm{H}_{0} \text { tidak } \\
\text { ditolak sehingga dapat disimpulkan } \beta_{2} \\
=0 \text { (koefisien tidak layak masuk } \\
\text { model regresi) atau dengan kata lain } \\
\text { variabel independen tersebut kurang } \\
\text { berpengaruh signifikan terhadap } \\
\text { variabel dependen. }\end{array}$ \\
\hline $\begin{array}{l}\text { Tingkat } \\
\text { Pengelolaan } \\
\text { Persampahan }\end{array}$ & 0.000 & 6.846 & $\begin{array}{l}\text { Karena P-value kurang dari } \alpha \text { atau }|t| \\
\text { lebih besar dari } t \text { (0.025; 192) maka } \mathrm{H}_{0} \\
\text { ditolak sehingga dapat disimpulkan } \beta_{3} \\
\neq 0 \text { (koefisien layak masuk model } \\
\text { regresi) atau dengan kata lain variabel } \\
\text { independen tersebut berpengaruh } \\
\text { signifikan terhadap variabel dependen. }\end{array}$ \\
\hline $\begin{array}{l}\text { Tingkat } \\
\text { Keteraturan } \\
\text { Bangunan }\end{array}$ & 0.000 & 44.147 & $\begin{array}{l}\text { Karena P-value kurang dari } \alpha \text { atau }|t| \\
\text { lebih besar dari } t \text { (0.025; 192) maka } \mathrm{H}_{0} \\
\text { ditolak sehingga dapat disimpulkan } \beta_{4} \\
\neq 0 \text { (koefisien layak masuk model } \\
\text { regresi) atau dengan kata lain variabel } \\
\text { independen tersebut berpengaruh } \\
\text { signifikan terhadap variabel dependen. }\end{array}$ \\
\hline $\begin{array}{l}\text { Tingkat Kepadatan } \\
\text { Bangunan }\end{array}$ & 0.000 & 7.895 & $\begin{array}{l}\text { Karena P-value kurang dari } \alpha \text { atau }|\mathrm{t}| \\
\text { lebih besar dari } \mathrm{t}(0.025 ; 192) \text { maka } \mathrm{H}_{0} \\
\text { ditolak sehingga dapat disimpulkan } \beta_{5} \\
\neq 0 \text { (koefisien layak masuk model } \\
\text { regresi) atau dengan kata lain variabel } \\
\text { independen tersebut berpengaruh } \\
\text { signifikan terhadap variabel dependen. }\end{array}$ \\
\hline
\end{tabular}


Berdasarkan uji koefisien tersebut, maka dapat dilihat pengaruh tiap variabel terhadap kualitas lingkungan permukiman dari masing-masing variabel sebagai berikut:

a. Tingkat Pengeluaran Kepala Keluarga memiliki P-value sebesar 0.271 dan t sebesar 1.104. Karena P-value lebih besar dari $\alpha$ atau $|t|$ kurang dari $t(0.025 ; 192)$ maka H0 tidak ditolak sehingga dapat disimpulkan $\beta 2=0$ (koefisien tidak layak masuk model regresi) atau dengan kata lain variabel independen tersebut tidak berpengaruh signifikan terhadap variabel dependen.

b. Tingkat Pengelolaan Persampahan memiliki P-value sebesar 0.000 dan t sebesar 6.846. Karena P-value kurang dari $\alpha$ atau $|t|$ lebih besar dari $t(0.025 ; 192)$ maka H0 ditolak sehingga dapat disimpulkan $\beta 3 \neq 0$ (koefisien layak masuk model regresi) atau dengan kata lain variabel independen tersebut berpengaruh signifikan terhadap variabel dependen.

c. Tingkat Keteraturan Bangunan memiliki P-value sebesar 0.000 dan t sebesar 44.147. Karena P-value kurang dari $\alpha$ atau $|t|$ lebih besar dari $t(0.025$; 192) maka H0 ditolak sehingga dapat disimpulkan $\beta 4 \neq 0$ (koefisien layak masuk model regresi) atau dengan kata lain variabel independen tersebut berpengaruh signifikan terhadap variabel dependen.

d. Tingkat Kepadatan Bangunan memiliki P-value sebesar 0.000 dan t sebesar 7.895. Karena P-value kurang dari $\alpha$ atau $|t|$ lebih besar dari $t(0.025$; 192) maka H0 ditolak sehingga dapat disimpulkan $\beta 5 \neq 0$ (koefisien layak masuk model regresi) atau dengan kata lain variabel independen tersebut berpengaruh signifikan terhadap variabel dependen.

\section{Kesimpulan}

Keberadaan program KOTAKU membawa dampak positif di Kelurahan Semanggi. Hal ini dapat terlihat dari penurunan luas permukiman kumuh di Kelurahan Semanggi sebesar 57,67 ha dari semula tahun 2017 sebesar 76,03 ha menjadi 18,36 ha di tahun 2020. Faktor fisik yaitu kepadatan bangunan, keteraturan bangunan dan pembuangan sampah mempunyai pengaruh yang besar terhadap peningkatan kualitas lingkungan permukiman. Hal ini dikarenakan program KOTAKU mempunyai kegiatankegiatan yang fokus pada peningkatan aspek fisik permukiman kumuh, seperti pembangunan rusunawa, relokasi permukiman ilegal, pembangunan saluran drainase, pengadaan sarana dan prasarana persampahan sehingga terjadi peningkatan kualitas lingkungan permukiman. Faktor sosial ekonomi masih memerlukan perhatian dari pemerintah karena dari hasil penelitian terlihat bahwa variabel sosial ekonomi seperti penghasilan kepala keluarga dan pengeluaran kepala keluarga kurang berpengaruh terhadap peningkatan kualitas lingkungan permukiman kumuh. Diperlukan akselerasi program di bidang sosial ekonomi terkait pengelolaan keuangan dan menumbuhkan kesadaran masyarakat tentang pola dan perilaku hidup sehat. 
Identifikasi Spasial Kualitas Lingkungan Permukiman Kumuh Di Kelurahan Semanggi

Kota Surakarta

\section{BIBLIOGRAFI}

Banawi, Anasufi. (2017). Jurnal; Pemahaman wujud zat dan perubahannya mahasiswa calon guru dan solusi reflektif (studi pada salah satu perguruan tinggi di Maluku). Inovasi, 11(2), 147-156.Google Scholar

Daniella, Andi Sasha, \& Widyastuti, Dyah. (2019). Kualitas Permukiman dan Karakteristik Sosial Ekonomi di Kecamatan Umbulharjo. Jurnal Bumi Indonesia, 8(1). Google Scholar

Dewi, Indira Kurnia, \& Idajati, Hertiari. (2020). Identifikasi Faktor Internal dan Faktor Ekternal Permukiman Kumuh di Kawasan Peri Urban (Studi Kasus: Sidoarjo Peri Urban Surabaya). Jurnal Teknik ITS, 8(2), C162-C168. Google Scholar

Ekartaji, Prittaningtyas, Yunus, Hadi Sabari, \& Rahardjo, Noorhadi. (2016). Kajian Kualitas Lingkungan Permukiman di Daerah Pinggiran Kota Kasus di Desa Ngestiharjo, Yogyakarta. Majalah Geografi Indonesia, 28(1), 96-102. Google Scholar

Ervianto, Wulfram I., \& Felasari, Sushardjanti. (2019). Pengelolaan permukiman kumuh berkelanjutan di perkotaan. Jurnal Spektran, 7(2), 178-186. Google Scholar

Ghozali, Ahmad, \& Sudaryatno, Sudaryatno. (2016). Pemanfaatan Citra Penginderaan Jauh dan Sistem Informasi Geografis untuk Zonasi Kerawanan Banjir di DAS Kalikemuning Kabupaten Sampang, Madura. Jurnal Bumi Indonesia, 5(4). Google Scholar

Hariyanto, Asep. (2010). Strategi penanganan kawasan kumuh sebagai upaya menciptakan lingkungan perumahan dan permukiman yang sehat (contoh kasus: kota Pangkalpinang). Jurnal Perencanaan Wilayah Dan Kota UNISBA, 7(2), pp11.Google Scholar

Hidayah, Nurul, Budiati, Wahyu, \& Permadi, Andre Seno. (2018). Analisis Hubungan Kualitas Lingkungan Permukiman Dan Kondisi Kesehatan Masyarakat Dengan Pemanfaatan Penginderaan Jauh Dan Sistem Informasi Geografis. Proceeding Of The URECOL, 280-289. Google Scholar

Krisandriyana, Maresty. (2017). Faktor Yang Mempengaruhi Keberadaan Kawasan Permukiman Kumuh Di Surakarta. Google Scholar

Liandri, Berta. (2019). Evaluasi Program Kotaku (Kota Tanpa Kumuh) Kelurahan Lebakgee Kecamatan Coblong Kota Bandung. Universitas Komputer Indonesia. Google Scholar

Mutaáli, Lutfi. (2016). Perkembangan Permukiman Kumuh di Indonesia Dari Masa ke Masa, Bulaksumur. Yogyakarta: Gadjah Mada University Press. 
Muvidayanti, Salma. (2018). Karakteristik Dan Faktor Penyebab Permukiman Kumuh Di Kelurahan Tanjung Mas Kota Semarang. Unnes. Google Scholar

Nurhasanah, Nurhasanah. (2019). Implementasi Kebijakan Program KOTAKU (Kota Tanpa Kumuh) Dalam Upaya Meningkatkan Kesejahteraan Masyarakat. Jurnal Inovasi Ilmu Sosial Dan Politik (JISoP), 1(1), 58-70. Google Scholar

Sabila, Timami. (2019). Perkembangan dan Faktor yang Mempengaruhi Munculnya Permukiman Kumuh di Kelurahan Tegalsari Kota Tegal (Tahun 2007-2017). UNNES. Google Scholar

Sinaga, E. (2018). Evaluasi Program Kota Tanpa Kumuh (KOTAKU) di Kelurahan Karangwaru, Kecamatan Tegalrejo. Universitas Gadjah Mada.

Umum, Kementrian Pekerjaan. (2016). Perumahan Rakyat Direktorat Jendral Cipta Karya "Petunjuk Pelaksanaan Dana Alokasi Khusus (DAK)"Bidang Infrstruktur Sub Bidang Sanitasi. Tahun.Google Scholar

Yayuk, Sri, \& Sugiyono, Sugiyono. (2019). Pengaruh kepemimpinan kepala sekolah dan biaya pendidikan terhadap kualitas proses belajar mengajar dan dampaknya dengan kompetensi lulusan SMK di kabupaten Gunungkidul. Jurnal Akuntabilitas Manajemen Pendidikan, 7(1), 84-96. Google Scholar

\section{Copyright holder:}

Andhika Bangun Taji (2021)

\section{First publication right:}

Syntax Idea

This article is licensed under: 